\title{
The relevance of coordinated regional trade logistics for the implementation of regional free trade area of Africa
}

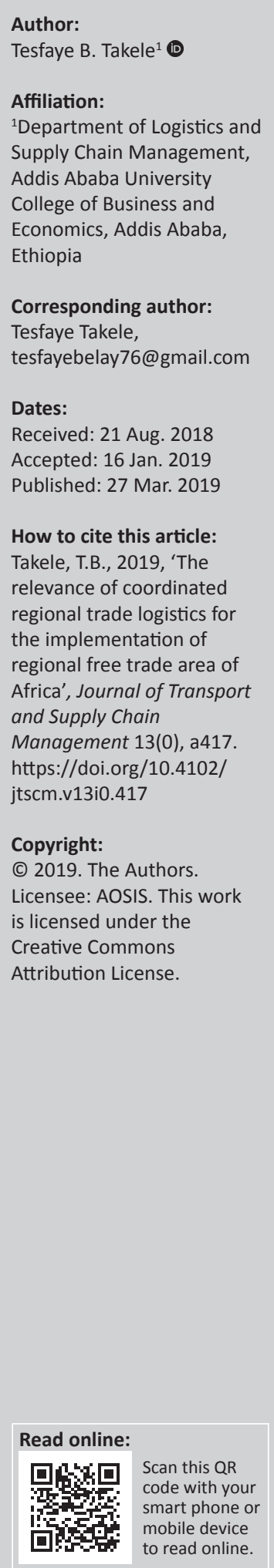

Background: Logistics will play a vital role in the process of boosting intra-regional trade among member states. Despite logistics integrating role in trade between countries, generally, African countries had faced with formidable challenges in logistics infrastructures development, and customs and border clearance.

Objectives: The main objective of this article was to analyse the effect of trade logistics performance on the intra-regional trade of Africa. African countries' logistics performance in international trade was measured using the World Bank Logistics Performance Index (LPI) and its components. The article emphasized examining the relevance of trade logistics for the implementation of the Continental Free Trade Area of Africa.

Method: Descriptive analysis was undertaken to analyse African countries' trade logistics performance, based on 2010-2018 LPI measures. The gravity model of international trade with Heckman maximum likelihood regression was used to explore the effect of trade logistics performance on the intra-regional trade of Africa.

Results: African countries experience lowest average LPI score relative to its trading partner regions, particularly in terms of quality of trade- and transport-related infrastructures, customs, and border clearance, and competency and quality of logistics services. The study on gravity model estimates shows that improvement in any of LPI components, that is, infrastructures development, customs clearance, competence and logistics service quality, international shipments, tracking and tracing, and timeliness, can lead to significant growth on the trade between African countries. However, being geographically landlocked has a statistically significant negative effect on bilateral trade flow.

Conclusion: Successful improvement in African countries' trade logistics performance including logistics infrastructure, customs clearance, and logistics service quality will enhance trade between African countries. This, in turn, will have a paramount contribution to the effective implementation of the Continental Free Trade Area of Africa.

Keywords: trade logistics; Logistics Performance Index; intra-regional trade.

\section{Introduction}

There are evidences which show that the share of African region in the global market areas is small, with a dramatic fall. For instance, Africa's merchandise exports to the global market were $7.3 \%$ in $1948,4.8 \%$ in 1973, 2.5\% in 1993, 2.4\% in 2003 and 2.2\% in 2016 (WTO 2017). Although there are many plausible reasons for lower trade performance of Africa in international trade, domination of African export by few products and weak regional integration were the two main reasons. Primary commodities such as fuel, mining products and agricultural products had dominated African countries' exports (WTO 2013).

In the last few years, there was a marked difference between Africa and other regions in terms of intra-regional trade share. For example, in 2016, intra-regional export was 67\% in Europe, 58\% in Asia, 48\% in North America and Latin America, and 20\% in the Caribbean. However, the share of African countries' intra-regional trade has continued as low. Out of the region's total merchandise export, intra-regional export of Africa was only 16\% in the same year (Mwaba 2017). African Union (AU) expects boost on the intra-regional trade of Africa when the region's countries implement regional-level economic integration initiatives, that is, Continental Free Trade Area (Economic Commission for Africa 2017). 
To promote greater trade flows between African countries, 44 African heads of states have signed the draft agreement on the establishment of the Continental Free Trade Area on 21 March 2018 (African Union 2018). The African Continental Free Trade Area (AfCFTA) is in-line with the AU's Agenda 2063 which seeks building a prosperous and united Africa. The African Continental Free Trade Area is a free trade agreement among African countries for trade in goods and services, and is also a key pillar and driver in the realisation of AU's Agenda 2063 (UNCTAD 2016).

The general aim of AfCFTA is to promote a sustainable socioeconomic development in the entire region through creating a single market for goods and services. African Union will realise the free market through eliminating tariff and nontariff barriers in goods, progressive trade liberalisation in services, cooperation in all trade-related areas and the establishment of an institutional framework for implementing the Continental Free Trade Area of Africa. The establishment of the continental customs union will follow the free trade area, which will enable the adoption of common external tariffs (AU 2018). African Union undertakes several integration initiatives including transport infrastructure development (UNCTAD 2016).

\section{Statement of the problem}

At the 2012 AU summit, heads of states and governments have adopted the decision on boosting intra-African trade (Assembly/AU/Dec.394 [XVIII]) through the establishment of the Continental Free Trade Area that should be operationalised by the indicative date of 2017. Heads of states had also agreed to launch negotiations on the liberalisation of trade in goods and services with an action plan which shows seven areas of cooperation, namely, trade facilitation, trade policy, trade-related infrastructure, productive capacity, trade finance, trade information and factor market integration (UNCTAD 2016). Regional economic integration needs to go beyond tariff reduction and shall improve connectivity through efficient trade logistics infrastructure developments, harmonisation of regulations and elimination of non-tariff barriers to enhance the region's integration with global value chains (Saygili, Peters \& Knebel 2018). Although tariff removal promotes export, trade infrastructure development, which is, road, railway and communication networks, is very important for regional integration in Africa (Rippel 2011).

Unfortunately, lack of diversity in export products, weak institutions, low level of industrial development and transport infrastructure deficiency are the main hindrances for the growth of intra-Africa trade other than tariff barriers. The region's infrastructure gap has reduced African firms' international competitiveness through increasing production and distributions costs (Mariam 2018). The World Bank has estimated that $\$ 93$ billion will be required annually through to 2020 to close Africa's infrastructure gap (The Economist 2014). Specific logistics hindrances for trade between African countries include the following: time lost at checkpoints, differences in rail gauges, limited capacity of infrastructures, deterioration of the region's logistics infrastructures, lack of harmonised customs or border formalities and several African countries do not have direct access to the sea (NEPAD 2016). Corruption at the border, long and bureaucratic customs procedures and security problems also hamper transportation of goods between African countries (Dabrowski \& Myachenkova 2018).

In the last three decades, Africa has taken enormous trade liberalisation efforts; however, excessive cost of moving goods has impeded the region's international trade growth. For instance, the cost of moving domestically remains high up to five times higher in Africa than in the United States. This requires efforts to reduce unnecessary intra-national trade costs which are increasing trading cost between countries (Donaldson, Jinhage \& Verhoogen 2017). Trading cost refers to all costs incurred in moving goods from local production to foreign customers such as tariff barriers, legal and regulatory costs, information cost and contract enforcement cost (Anderson \& Van Wincoop 2004).

In many economies, inefficient trade and transport processes, unnecessary bureaucracy and redundant procedures had increased the cost and time for border and documentary compliance (World Bank 2016b). Even though the required number of days for export showed a reduction, it requires traders to invest $50 \%$ more time on export clearance in Africa than in East Asia (Donaldson et al. 2017).

A significant gap had emerged with regard to the time required to export goods between Africa and other regions. It takes a very long time for African countries to export goods through complying with all necessary procedures than its trading partners (World Bank 2016a). Table 1 illustrates the comparison between European Union, sub-Saharan Africa and China on the time and cost to export based on World Bank report. For instance, it takes 8.1 hours for the European Union to clear export associated with border compliance with customs clearance and inspection by government agencies in 2016. Yet, it takes $103 \mathrm{~h}$ for sub-Saharan Africa to clear exports in the same year (World Bank 2018a). Reducing such unnecessary delays could have a dramatically positive effect on export volumes (Arvis et al. 2016).

World Bank measures countries' logistics performance in international trade to identify their challenges and opportunities for further improvements. Huge logistics performance gap has manifested between top- and lowperforming countries. The average Logistics Performance

TABLE 1: Time and cost to export, border compliance.

\begin{tabular}{lcc}
\hline Region/Country & Time (h) & Cost (USD) \\
\hline European Union & 8.1 & 85.2 \\
Sub-Saharan Africa & 103.0 & 579.8 \\
China & 25.9 & 484.1 \\
India & 106.1 & 413.1 \\
South Africa & 100.0 & 428.0 \\
Uganda & 71.0 & 209.0 \\
\hline
\end{tabular}

USD, United States dollar; h, hours. 
Index (LPI) for African countries in 2016 shows that African countries had lower performance, with an average score of 2.43. The region experiences lower performance in terms of trade- and transport-related infrastructures development, and customs and border management (World Bank 2016c). In fact, North Africa's economies have better infrastructures development. However, the overall Africa has witnessed slow infrastructures development compared to other regions. Supply of an adequate amount and quality transport and communication infrastructures are insufficient. This has become one of the major impediments for improving trade in Africa (World Economic Forum 2013).

In 2009, the World Bank had investigated Africa's infrastructure challenges for establishing a baseline for future improvements. Addressing the region's infrastructure spending needs \$93bn per year (Foster \& Briceño-Garmendia 2009). Approximately $60 \%$ of Africa's population lacks access to modern infrastructures, which makes it difficult of getting proper access to health care, education and jobs (OSAA 2015). Figure 1 shows railway infrastructure development of subSaharan Africa, European Union and other selected countries. There is a big difference between sub-Saharan Africa and EU countries in terms of total rail lines. This can be an example for Africa's infrastructure gap with the rest of the world.

Although there are several factors that determine effective implementation of the region's free trade agreement, researchers have also acknowledged positive contribution of quality logistics service on countries' international trade competitiveness. While measuring the impact of different sources of trade cost on international trade, Hoekman and Nicita (2011) have confirmed that improving countries' logistics performance and reducing trading cost will have a higher contribution on trade benefits. Besides cost reduction, quality physical infrastructures development, such as roads, railways and ports, will enhance developing countries' international trade competitiveness (Portugal-Perez \& Wilson 2012).

Trade- and transport-related infrastructures development and efficient linkages are prerequisites for successful regional trade agreements. African countries' international trade competitiveness and logistics have been studied by several

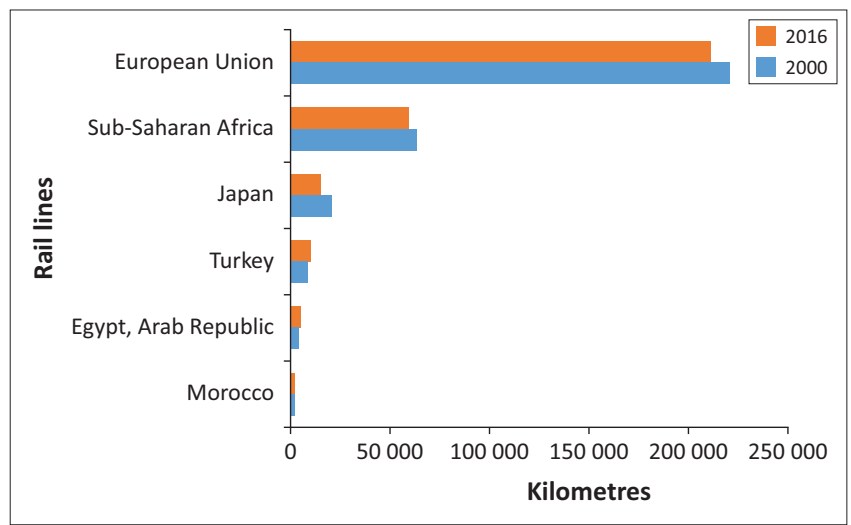

FIGURE 1: Rail lines (total route, km). researchers (Geda \& Seid 2015; Ogunyemi 2017; Seid 2013; Saygili et al. 2018). However, there is a research gap on studying the role of African countries' logistics performance on the region's intra-regional trade. It is important to provide concrete evidence to support the successful implementation of the Continental Free Trade Area of Africa. Hence, the primary concern of this study is to examine the effect of trade logistics performance of Africa on its intra-regional trade.

\section{Theoretical framework}

\section{Regionalism}

African Union had realised that the region's countries are not getting tangible benefits from globalisation and international agreements. As a result, the AU has announced a strategic framework for the socio-economic development of the continent called New Partnership for Africa's Development (NEPAD) in 2001. This programme aims at eradicating poverty, ensuring sustainable development in the region (Farrell et al. 2005). A region refers to a group of countries with geographic proximity, social and cultural homogeneity, shared political attitudes and political institutions, and economic interdependence (Russett 1967). As the focus of this article is regional logistics coordination, the researcher selected the theory of regionalism to build a better theoretical foundation and analysis regarding the different sides of regional integration.

Regionalism results from regions' efforts to respond to a different push and pull factors, in particular to historical, social and political conditions by creating cooperation with different settings of a regional framework. Farrell et al. (2005) viewed regionalism as a multidimensional form of integration which comprises economic, cultural, political and social aspects with purposes that will exceed the creation of free trade agreements. One of the strategic goals of regionalism is building regional unity. Regionalism is useful to achieve a wide range of objectives that can include more rapid and fair improvement in terms of administrative efficiency, economic development, enhancing democracy and representation, promoting cultural identity, preserving the natural environment and motivating innovation (Soja 2009).

Most notably, regional integration may include three different aspects: economic integration, political integration and physical integration (Bolaños 2016). According to economic integration theory, economic integration refers to both a state of affairs and a process. As a state of affairs, it is the absence of numerous forms of discrimination between national economies. As a process, economic integration comprises actions designed to abolish discrimination between economic units belonging to different national states (Balassa 1961). Besides the economic benefits of economic integration, higher trade flows between neighbouring countries with a free trade agreement could reduce war between trading nations. Interdependence will make escalation of disputes less attractive (Morrow 1999). Thus, engagement in regional trade agreements will create a strong bond between 
neighbouring countries that will have a significant contribution to political stability and regional developments (Barnekow \& Kulkarni 2017).

Implementation of AfCFTA will create opportunities for access to all African countries' market. The free trade agreement has intended through incorporating all African countries with a population of about 1.2 billion and a combined gross domestic product (GDP) of $\$ 2.5 \mathrm{bn}$. Thus, a reduction in production cost by achieving economies of scale will be one benefit of AfCFTA. This will increase export volume in value-added products for intra- and inter-industry trade (African ExportImport Bank 2018). African Union has recognised eight regional trade communities as building blocks for Africa's economic integration (UNCTAD 2018). The continent regional trade agreements, that is, Economic Community of West African States, Southern African Development Community, Economic and Monetary Community of Central Africa, Union of Arab Maghreb, Common Market for Eastern and Southern Africa, West African Economic and Monetary Union are significantly contributing towards increasing trade between member and non-member countries. This encourages successful implementation of regionalism in Africa (Ngepah \& Udeagha 2018).

African Export-Import Bank carried an experiment on four different policy scenarios for implementing AfCFTA using the Global Trade Analysis Project (GTAP) Model. The study has evidence on the policy scenario that eliminates tariff on all trade, and reduces non-tariff barriers (NTBs) as the most beneficial form of AfCFTA arrangement for Africa in terms of macroeconomic and welfare benefits. Although there is a net gain from the continental free trade agreement of Africa, the region's countries will not equally benefit. This has resulted from differences in GDP, patterns of growth and efficiency in investment (African Export-Import Bank 2018).

Although tariff removals will lead to lower product prices for consumers, it may have negative effects on countries' earnings from tax. Import duties make up on average $15 \%$ of total tax revenue in Africa (African Tax Administration Forum 2017). An expected high level of trade creation and expansion from AfCFTA formation can compensate such revenue losses in the intra-Africa trade because of AfCFTA formation (UNCTAD 2015). Saygili, Peters and Knebel (2017) have carried an estimate on tariff revenue losses from AfCFTA taking two scenarios: full-liberalisation and partial tariff cuts. The result stated that welfare gains from intra-regional trade exceed the tariff revenue losses for Africa.

\section{Trade logistics}

\section{Performance and international trade competitiveness}

Trade logistics refers to several processes and services accomplished in delivering goods in cross-border transactions. These include customs clearance and administration, transportation, tracking and tracing, arrangement of international shipments, and information technology and communications. Trade logistics shall be determined at the national level (Korinek \& Sourdin 2011). Improved trade logistics performance will increase trading countries' abilities to respond to international orders at the right time with lower costs, that is, right time delivery will reduce inventory costs (Saslavsky \& Shepherd 2014).

The increasing complexity of global business has given the chance for logistics to play a pivotal role in determining the international competitiveness of countries (Martí, Puertas \& García 2014). For instance, improving performance on trade-related logistics services such as infrastructure, logistics service, port efficiency and information system is critical to enhancing countries' competitiveness on trading products at the right time with lower cost (Arvis et al. 2007). Time to market is a very important competitive factor and a barrier to trade. Lengthy export and import procedures may reduce companies' chance to enter into an export market for time-sensitive products, that is, cloth and consumer electronics, and affect the volume of trade (Nordås, Pinali \& Grosso 2006).

Improvement in logistics performance will contribute to the increasing volume of export. While investigating EU countries' logistics performance improvement (2005-2010) using the World Bank LPI and its six dimensions, logistics has found with an important contribution for both exporting and importing countries (Puertas, Martí \& García 2013). Based on gravity model estimates on the importance of logistics in international trade for emerging regions, that is, Far East, East Europe, Africa, Middle East and South America, all LPI components have a significant positive effect towards increasing international trade for both import and export (Martí et al. 2014). Based on the analysis of countries' merchandise trade, improvement in trade logistics performance will enhance overall trade performance for countries found at all level of development. Specific trade logistics performance components such as customs procedures, tracking and tracing, overall infrastructure and logistics competence have higher positive effects on bilateral merchandise trade (Korinek \& Sourdin 2011). Table 2 shows the importance of logistics performance on EU-26 export in 2010.

\section{Purpose of the study}

The main purpose of this study is to examine the strategic importance of trade logistics coordination for effective

TABLE 2: Logistics coefficients of EU-26 in 2010.

\begin{tabular}{lll}
\hline Logistics variables & Export & Import \\
\hline LPI & $0.251^{* * *}$ & $0.148^{* *}$ \\
Customs & $0.229 * * *$ & $0.084^{*}$ \\
Infrastructure & $0.282^{* * *}$ & $0.141^{* *}$ \\
International shipments & $0.135^{* * *}$ & $0.131^{* * *}$ \\
Competence & $0.298^{* * *}$ & $0.101^{*}$ \\
Tracking & $0.213^{* * *}$ & $0.154^{* * *}$ \\
Timeliness & $0.091^{*}$ & $0.126 * * *$ \\
\hline
\end{tabular}

Source: Puertas, R., Martí, L. \& García, L., 2013, Logistics performance and export competitiveness: European experience, Springer Science+Business Media, New York.

LPI, Logistics Performance Index; EU-26, European Union-26.

$*, * *$ and $* * *$ denote test statistical significance at the $10 \%, 5 \%$ and $1 \%$ levels, respectively. 
implementation of the AfCFTA. Specific issues which are addressed by this research include investigation of African countries' trade logistics performance based on the World Bank LPI measure, and measure the effect of LPI dimensions on bilateral trade flows for the effective implementation of the Continental Free Trade Area of Africa.

\section{Research methods}

The subject area of this study is countries found in Africa. The article has examined trade logistics coordination of Africa towards implementing the region's free trade agreement. As a result, intra-regional trade of Africa is the dependent variable, measured by the value of African countries' merchandise export in bilateral trade within Africa. Bilateral export value comprises all commodities classified under Standard International Trade Classification Revision 1 (SITC Rev.1). Besides gravity model core variables, the model includes LPI dimensions in the explanatory variables list to measure the effect of trade logistics on bilateral trade flows.

The researcher carried descriptive analysis incorporating all African countries, which have been part of 2010-2018 LPI survey. International trade gravity model was also applied to explore the effect of LPI dimensions on bilateral trade flows. In the study gravity dataset, both the source and destination countries are African countries. The study gravity dataset was built with 25 sources and 43 destination countries. Thus, the gravity dataset comprises $25 \times 43=1075$ bilateral trade flows carried out in 2016. The researcher selected Africa countries with basic data, that is, LPI. The required data have been retrieved from international organisations databases such as UN Comtrade, World Bank Open Data and Centre d'Études Prospectives et d'Informations Internationales (CEPII).

This research applied a gravity model to estimate the effect of trade logistics performance on the value of bilateral trade between countries. Apart from gravity core variables such as GDP and distance, gravity equations may include other variables that will influence bilateral trade flows, such as trade policy and institutional variables (Portugal-Perez \& Wilson 2009). Numerous researchers have applied the gravity model to explore the effect of logistics on bilateral trade flows, (e.g. Hausman, Lee \& Subramanian 2005; Rocha \& Freund 2010; Portugal-Perez \& Wilson 2009). Bilateral trade gravity equations can be estimated for a cross-section of countries (Bacchetta et al. 2015). Puertas, Martí and García (2014) explored the importance of trade logistics performance in countries' bilateral trade flows using European countries' LPI. The researchers had estimated several gravity equations using LPI components as proxy variables for trade facilitation. This research applied similar gravity equations as presented below.

$\log \left(Y_{i j}\right) \beta_{0}+\beta_{1} \log \left(\mathrm{D}_{i j}\right)+\beta_{2} \log \left(\mathrm{GDP}_{i}\right)+\beta_{3} \log \left(\mathrm{GDP}_{j}\right)$

$+\beta_{4} \log \left(\mathrm{LIP}_{i}\right)+\beta_{5} \log \left(\mathrm{LIP}_{j}\right)+\beta_{A}(W)+U_{i j}$

[Eqn 1] where $Y_{i j}$ is the value of export from country $i$ to country $j ; i$ is the exporter countries; $j$ is the importer countries; $D_{i j}$ is the geographical distance between trading countries; $\mathrm{GDP}_{i}$ is the exporter countries' gross domestic product; GDP is the importer countries' gross domestic product; $\mathrm{LPI}_{i}$ is the exporter countries' Logistics Performance Index; LPI is the importer countries' Logistics Performance Index; $W$ is the set of dummy variables (common border, official language, common colony, landlocked) and $U_{i j}$ is the error term.

According to the above equation, the value of export from country $i$ to country $j$ is a function of origin (exporting) and destination (importing) countries' economic size, distance between trading countries and logistics performance of both exporting and importing countries. Dummy variables for a common border, official language and a common coloniser have used as a proxy for trade cost. A dummy variable for direct access to the sea (landlocked) has included to investigate the effect of direct access to the sea on bilateral trade flows. In modelling gravity equations and conducting estimation, it has recommended developing a separate equation for each LPI components to avoid multicollinearity among trade logistics performance indicators (Puertas et al. 2013). As a result, separate equations have derived for each LPI components that include customs (Eqn 2), infrastructure developments (Eqn 3), international shipments (Eqn 4), competence and quality of logistics service (Eqn 5), tracking and tracing (Eqn 6) and timeliness (Eqn 7).

$\log \left(Y_{i j}\right)=\beta_{0}+\beta_{1} \log \left(D_{i j}\right)+\beta_{2} \log \left(G D P_{i}\right)+\beta_{3} \log \left(G D P_{j}\right)$ $+\beta_{4} \log \left(\right.$ Customs $\left._{i}\right)+\beta_{5} \log \left(\right.$ Customs $\left._{j}\right)+\beta_{A}(W)+U_{i j}$

[Eqn 2]

$\log \left(Y_{i j}\right)=\beta_{0}+\beta_{1} \log \left(D_{i j}\right)+\beta_{2} \log \left(G D P_{i}\right)+\beta_{3} \log \left(G D P_{j}\right)+\beta_{4}$ $\log \left(\right.$ Infrastructure $\left._{i}\right)+\beta_{5} \log \left(\right.$ Infrastructure $\left._{j}\right)+\beta_{A}(W)+U_{i j} \quad$ [Eqn 3]

$\log \left(Y_{i j}\right)=\beta_{0}+\beta_{1} \log \left(D_{i j}\right)+\beta_{2} \log \left(G D P_{i}\right)+\beta_{3} \log \left(G D P_{j}\right)$

$+\beta_{4} \log \left(\right.$ Shipments $\left._{i}\right)+\beta_{5} \log \left(\right.$ Shipments $\left._{j}\right)+\beta_{A}(W)+U_{i j}$

[Eqn 4]

$\log \left(Y_{i j}\right)=\beta_{0}+\beta_{1} \log \left(D_{i j}\right)+\beta_{2} \log \left(G D P_{i}\right)+\beta_{3} \log \left(G D P_{j}\right)$

$+\beta_{4} \log \left(\right.$ Quality $\left._{i}\right)+\beta_{5} \log \left(\right.$ Quality $\left._{j}\right)+\beta_{A}(W)+U_{i j}$

[Eqn 5]

$\log \left(Y_{i j}\right)=\beta_{0}+\beta_{1} \log \left(D_{i j}\right)+\beta_{2} \log \left(G D P_{i}\right)+\beta_{3} \log \left(G D P_{j}\right)$

$+\beta_{4} \log \left(\right.$ Tracking $\left._{i}\right)+\beta_{5} \log \left(\right.$ Tracking $\left._{j}\right)+\beta_{A}(W)+U_{i j}$

[Eqn 6]

$\log \left(Y_{i j}\right)=\beta_{0}+\beta_{1} \log \left(D_{i j}\right)+\beta_{2} \log \left(G D P_{i}\right)+\beta_{3} \log \left(G D P_{j}\right)$ $+\beta_{4} \log \left(\right.$ Timeliness $\left._{i}\right)+\beta_{5} \log \left(\right.$ Timeliness $\left._{j}\right)+\beta_{A}(W)+U_{i j}$

[Eqn 7]

In international trade gravity model estimation, it is common to have zero-reported bilateral trade between trading countries, even in aggregated trade data (Shepherd 2013). An effective method of handling zero bilateral trade is to use a Heckman sample selection model (Heckman 1979). However, this research data test does not provide sound evidence on homoscedasticity test. The right countermeasure for heteroscedasticity problem in gravity model is to use robust 
option (Shepherd 2013). As a result, this study has applied Heckman maximum likelihood estimation with a robust option. Thus, this study will precisely explain trade flows between African countries.

\section{Logistics Performance Index}

World Bank measures countries' trade logistics performance in international trade since 2007 using its measure known as the LPI. Logistics Performance Index reveals countries' challenges and opportunities for improvements on the areas of trade logistics. Improving logistics performance is vital to enhance a country's trade competitiveness. Inefficient logistics will raise the cost of trading and cut potential to maximise international trade (Arvis et al. 2014).

Logistics Performance Index survey has been carried out by the World Bank in collaboration with international and academic institutions and private companies involved in international logistics. Logistics Performance Index survey uses a standardised questionnaire which comprises domestic and international parts. For the domestic part, respondents provide qualitative and quantitative data towards logistics environment, cost and time in the countries where they are working. For the international part (international LPI), respondents evaluate countries' logistics performance with six key areas. A scale 1 (lowest) to 5 (highest) was used in rating performance (Arvis et al. 2014; Busch 2015). As the focus of this article is logistics operations in cross-border transactions, international LPI was used in this study. Logistics Performance Index comprises six performance indicators or components. The overall LPI is a weighted average score of its six indicators (Arvis et al. 2014).

World Bank classified LPI's six dimensions into two, input and outcome. Customs, infrastructure and logistics service quality are areas for policy regulations (inputs). Timeliness, international shipments, and tracking and tracing are outcomes represented by service delivery performance (Arvis et al. 2016). Logistics Performance Index survey comprises questions on the following six key performance areas:

- Customs analyse the efficiency of customs clearance and border management, that is, speed, simplicity and formalities predictability (Arvis et al. 2016).

- Infrastructure refers to the quality of trade- and transportrelated infrastructures that include roads, railways, transports, airports, warehousing, intermodal facilities, and information and communication technologies (Arvis et al. 2010).

- International shipments analyse the flows of goods regarding ease of arranging competitively priced international shipments (Arvis et al. 2016).

- Service quality assesses competence and quality of logistics service, for example, customs brokerage, trucking and forwarding. Logistics service quality is critical to assure a reliable supply chain to producers and exporters (Arvis et al. 2012).

- Tracking and tracing refer to the ability to track and trace consignments (Arvis et al. 2016).

- Timeliness analyses the frequency within which shipments reach consignees within scheduled or expected delivery times (Arvis et al. 2016).

\section{Comparative position of Africa in trade logistics performance}

While comparing average African countries' trade logistics performance with other regions based on 2018 LPI, Africa has scored the lowest overall logistics performance relative to all other comparable regions (Figure 2). The top-performing regions are North America and Europe, respectively.

\section{Logistics Performance Index of Africa}

According to the World Bank's logistics performance measure, that is, LPI, African region has scored the lowest performance. Although few African countries have higher logistics performance, on average the overall trade logistics performance of Africa is low. The logistics performance of region's countries in cross-border trade has characterised with a wider gap. Although Angola experienced lowest overall logistics performance in 2016 (2.05, minimum score), South Africa has a higher overall logistics performance (3.38, maximum score). South Africa was identified as one of overperformer country as per LPI measures, ranked as 20th out of 160 countries in 2016 (Havenga et al. 2016). Figure 3 shows the better and worst performing African countries in trade logistics as per 2018 LPI.

Figure 4 presents African countries' average trade logistics performance under the six LPI dimensions in five LPI measures. From 2010 to 2018 Africa region has scored on average less than 2.5 in overall LPI. There is also a wider performance gap under different components. Based on the average data presented in the graph below, African countries' lowest performance had observed in terms of

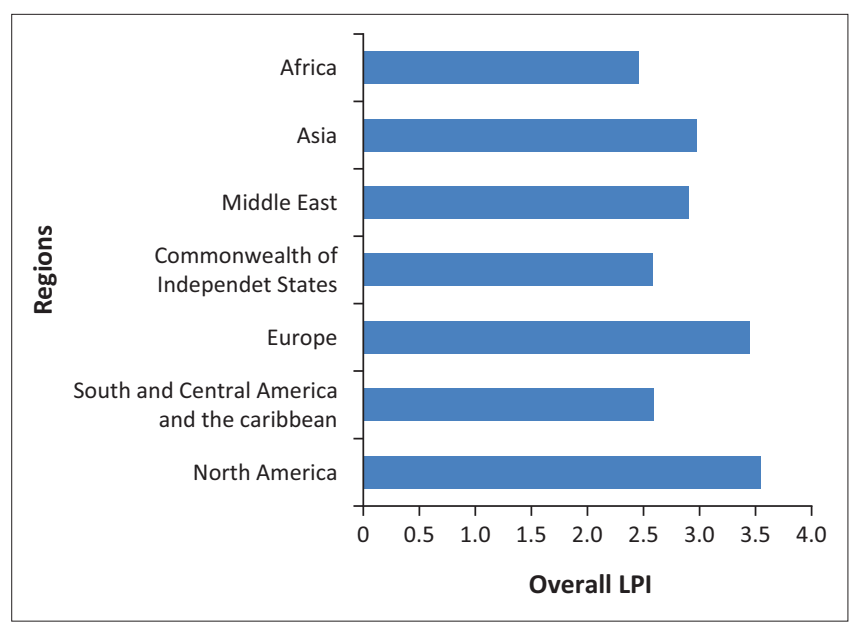

LPI, Logistics Performance Index.

FIGURE 2: World regions' overall Logistics Performance Index in 2018. 


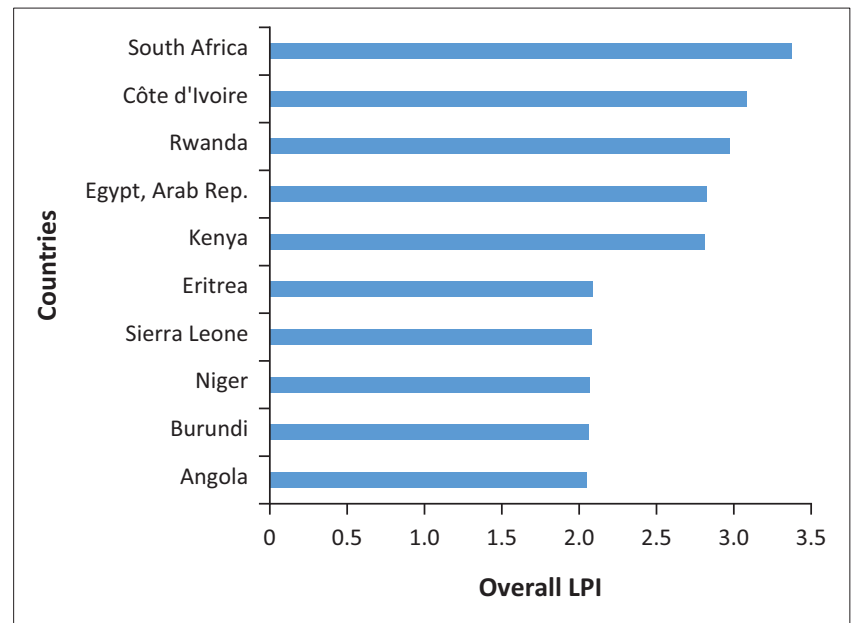

LPI, Logistics Performance Index.

FIGURE 3: Logistics Performance Index of African countries with better and lowest logistics in 2018.

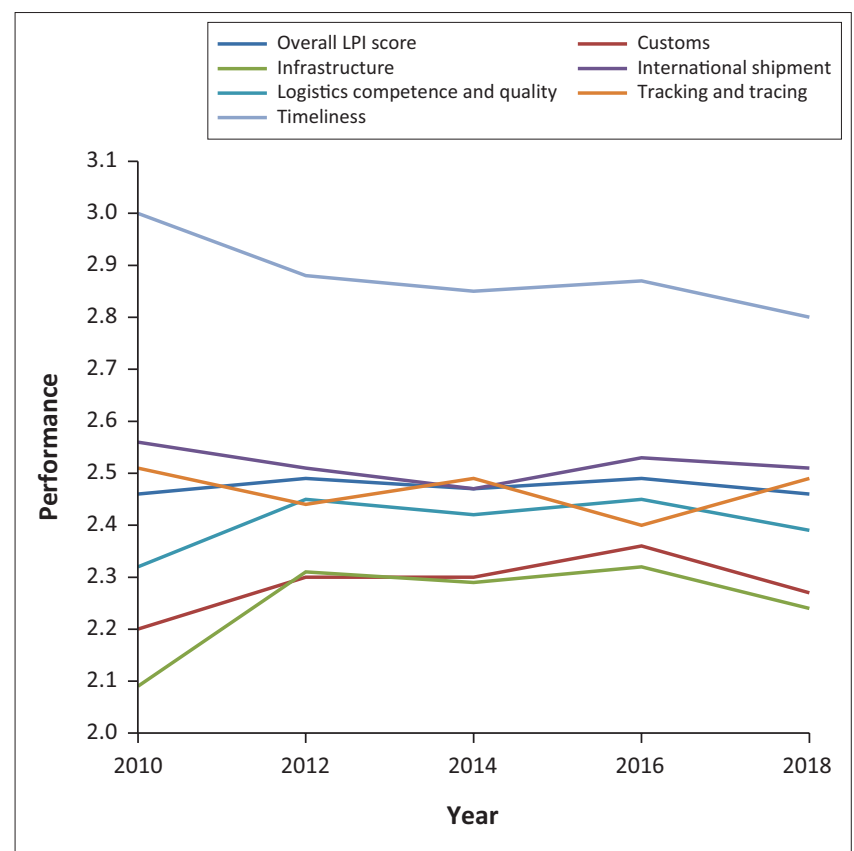

LPI, Logistics Performance Index.

FIGURE 4: Logistics performance of Africa in Logistics Performance Index six components.

quality of trade- and transport-related infrastructures developments, customs and border clearance, and competency and quality of logistics services, respectively. World Bank identified these three areas as an input for supply chain service deliveries. The region also had experienced lower performance in terms of ease of ability to track and trace consignments and arrange competitively priced international shipments. The region has relatively improved trade logistics performance in terms of on-time delivery of shipments. Unfortunately, almost no tangible improvement was marked from 2012 to 2018 in all LPI components. Based on these facts, African countries have to improve their trade logistics performance in all LPI dimensions. African countries shall give priority to promote investment in trade- and transport-related infrastructures and improve customs and border clearance.
This research investigated logistics performance difference between African countries based on their ability to direct access sea or not. There are 16 landlocked developing countries in Africa, whose international trade depends on transit sates for maritime access. In most cases, landlocked countries are surrounded by transit neighbours with similar economic problems (UN-OHRLLS 2014). Lack of direct access to sea, remoteness, isolation from international markets and infrastructure development deficiencies had created formidable challenges in promoting international trade for landlocked countries relative to coastal states (Chowdhury \& Erdenebileg 2006). Historically, coastal countries have higher trade logistics performance than their landlocked neighbouring countries (World Bank Group 2014). In accordance with World Bank regions' overall average LPI score 2007-2014 comparison for countries with similar level of incomes, coastal countries' LPI score is higher than their landlocked peers (Arvis et al. 2014). In this article, coastal African countries' average overall LPI has compared with landlocked African countries in Figure 5 under 2018 LPI. Similarly, African landlocked countries have lower trade logistics performance than their coastal neighbours. Even though the difference is not large enough, landlocked countries have a lower score in all LPI components. Thus, landlocked developing countries shall improve performance in trade-related logistics.

Transit and landlocked countries should exert joint efforts towards improving landlocked developing countries' traderelated logistics performance. These should include improvement of port-hinterland connections through soft and hard infrastructures developments (road, railways, air transport, ICT, institutional reform), optimise multimodal transport and transporting cargo by air (Arvis \& Dairabayeva 2014). There has been an increasing recognition of challenges and special needs of landlocked developing countries at the international level. In 1957, UN General Assembly had first recognised the need of landlocked countries for adequate transit facilities in promoting international trade by its resolution 1028 (XI) (Chowdhury \& Erdenebileg 2006). Recently, the UN-OHRLLS has prepared a 10-year programme, namely, Vienna Programme of Action for Landlocked Developing Countries for 2014-2024, based on strengthened partnerships between landlocked developing countries and the transit countries as well as their development partners. This programme aims at achieving more inclusive and sustainable growth through infrastructure development and maintenance, trade facilitation, regional integration and cooperation, and structural economic transformation in landlocked developing countries (UNOHRLLS 2014).

There is a persistent and large difference in logistics performance between countries with different income levels (World Bank Group 2014). Under 2018 LPI, middle-income African countries have lower logistics performance in all LPI dimensions than low-income African countries (see Figure 5). However, logistics performance is not only an issue of 


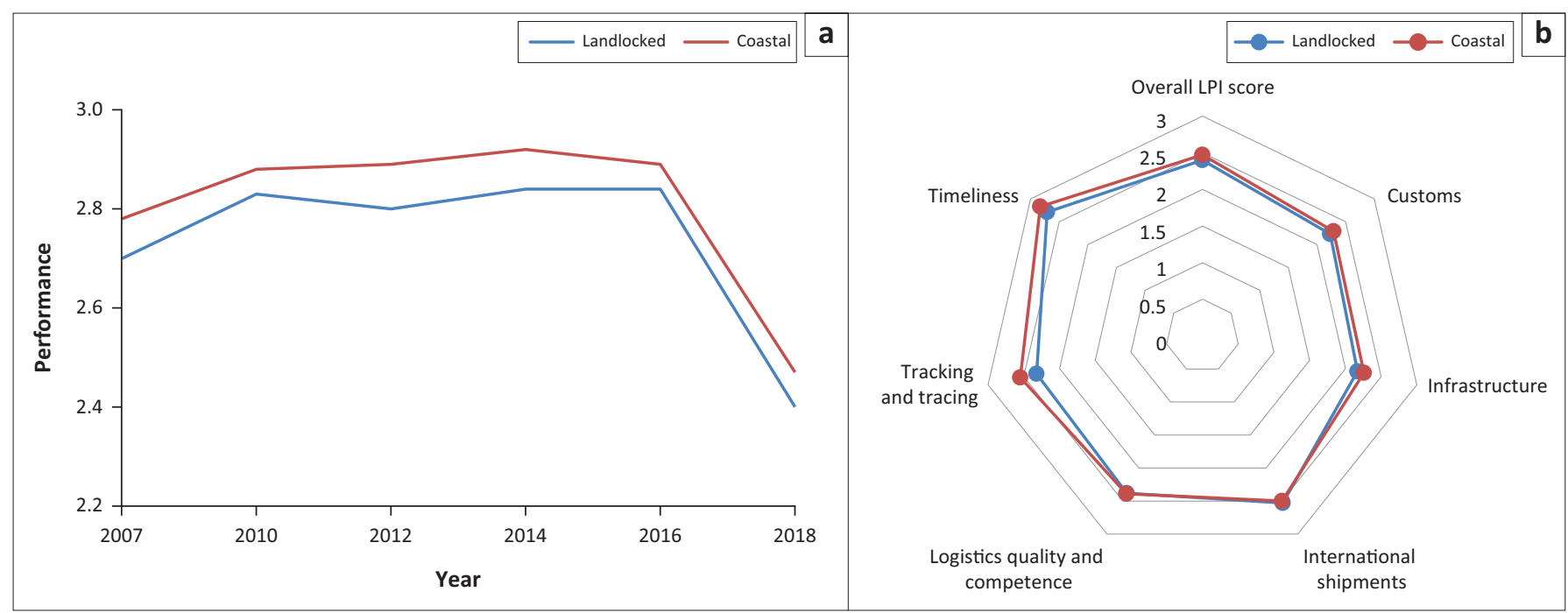

FIGURE 5: (a) Logistics Performance Index of coastal/landlocked and (b) low-income/high-Income African countries.

national income or development, but it heavily depends on the national government's policy and investment choices (McLinden et al. 2011). Low-income countries' logistics performance improvement has attributed to trade facilitation efforts in infrastructure and basic border management improvements (World Bank Group 2014).

\section{The effect of LPI on intra-regional trade of Africa}

Identifying the strategic role that African countries' national trade logistics performance will play on countries' bilateral trade flows requires studying the effect that national trade logistics performance will have on the region's countries bilateral trade flows. Regression estimation results and interpretation of the research gravity equations have been presented in the following sections.

The researcher carried Heckman Maximum likelihood estimation based on the research equations. The estimation result, as illustrated in Table 3, shows how the study explanatory variables affect export value in bilateral trade flows. The variables include bilateral distance, GDP, LPI, common border, language, colony and landlocked. The information contained on the study gravity equations estimates of the null hypothesis rho $=0$, that is, the selection and outcome equations' error terms are uncorrelated, had accepted in all equations. An implication of these results is that sample selection is not a problem in this research.

Gravity model core variables, that is, GDP and bilateral distance, have a statistically significant result as expected. The coefficient on geographical distance is negative and statistically significant. This implies that countries with longer geographical distance will trade less because of higher logistics cost. This finding suggests that geographical proximity has a significant contribution to the process of maximising trade flows between African countries. Regarding economic size, both importer and exporter GDP have a significant positive effect on bilateral trade flows.
An implication of this is the possibility that countries with bigger economic size will trade more.

Interestingly, statistically significant positive evidence had found on trade between countries that are sharing a border. Thus, countries with a common border have more trade flows than countries that do not. Contrary to expectations, a common official language and sharing colonial ties do not have statistically significant effects on trade between African countries. Further statistical tests revealed that the lack of direct access to the sea or being geographically landlocked have a statistically significant negative effect on bilateral trade. Thus, landlocked countries experience lower trade flows than their coastal neighbours.

The results of the regression estimate under each of LPI components prove the relevance of all LPI dimensions on bilateral trade flows. Both exporter and importer countries' logistics performance (LPI components) have statistically significant positive effects on bilateral trade flow with high level of significance $(p<0.01)$. These components are efficiency of quality of trade- and transport-related infrastructure, customs clearance and border management, arranging competitively priced international shipments, competence and quality of logistics services, ability to track and trace shipments, and frequencies within which shipments arrive on time. Exporter and importer countries' trade logistics performance under each LPI components confirmed the relevance of enhancement of trade logistics performance in increasing bilateral trade flows.

Both exporters and importer countries' logistics performance have statistically significant positive coefficients. Even though both exporters and importers' logistics performance experiences a different level of contribution for bilateral trade flows, import LPI dimensions have higher coefficients than export LPI. Despite LPI is relevant for source and destination countries, this research findings suggest that higher trade logistics performance is more relevant for 
TABLE 3: Effect of Logistics Performance Index on intra-regional trade of Africa.

\begin{tabular}{|c|c|c|c|c|c|c|c|}
\hline Trade & Eqn 1 & Eqn 2 & Eqn 3 & Eqn 4 & Eqn 5 & Eqn 6 & Eqn 7 \\
\hline Distance & $-1.912 * * *$ & $-1.996 * * *$ & $-1.924 * * *$ & $-2.009 * * *$ & $-1.802 * * *$ & $-1.675 * * *$ & $-1.821 * * *$ \\
\hline GDP export & $1.046 * * *$ & $1.139 * * *$ & $1.080 * * *$ & $1.018 * * *$ & $1.008 * * *$ & $1.048 * * *$ & $1.098 * * *$ \\
\hline GDP import & $0.488 * * *$ & $0.613 * * *$ & $0.5245 * * *$ & $0.556 * * *$ & $0.381 * * *$ & $0.416^{* *}$ & $0.522 * * *$ \\
\hline LPI export & $3.038 * * *$ & - & - & - & - & - & - \\
\hline LPI import & $3.866 * * *$ & - & - & - & - & - & - \\
\hline Customs export & - & $2.615 * * *$ & - & - & - & - & - \\
\hline Infrastructure export & - & - & $1.898 * * *$ & - & - & - & - \\
\hline Infrastructure import & - & - & $3.177 * * *$ & - & - & - & - \\
\hline Shipments export & - & - & - & $4.124 * * *$ & - & - & - \\
\hline Shipments import & - & - & - & $3.487 * * *$ & - & - & - \\
\hline Quality export & - & - & - & - & $2.470 * * *$ & - & - \\
\hline Quality import & - & - & - & - & $3.818^{* * *}$ & - & - \\
\hline Tracking export & - & - & - & - & - & $1.528 * *$ & - \\
\hline Timeliness export & - & - & - & - & - & - & $2.189 * * *$ \\
\hline Timeliness import & - & - & - & - & - & - & $3.031 * * *$ \\
\hline Border & $1.917 * * *$ & $1.941 * * *$ & $2.008 * * *$ & $1.856 * * *$ & $1.948 * * *$ & $2.054 * * *$ & $1.971 * * *$ \\
\hline Official language & 0.203 & 0.286 & 0.194 & 0.269 & 0.133 & 0.190 & 0.243 \\
\hline Common colony & $0.470 *$ & 0.400 & 0.334 & $0.505^{* *}$ & 0.381 & 0.314 & 0.391 \\
\hline Landlocked & -1.917 & $-2.056 * * *$ & $-1.857 * * *$ & $-1.95 * * *$ & $-1.83 * * *$ & $-1.72 * * *$ & $-1.816 * * *$ \\
\hline Constant & -10.63 & $-12.93 * * *$ & $-10.10 * * *$ & $-11.19 * * *$ & $-7.96 * *$ & $-8.39 * *$ & $-12.261 * * *$ \\
\hline
\end{tabular}

GDP, gross domestic product; LPI, Logistics Performance Index; Eqn, equation.

$* * *, * *, *$ test statistical significance at $1 \%, 5 \%$ and $10 \%$ levels, respectively.

importing countries in intra-regional trade of Africa. The findings of this study support that improvement in both exporter and importer countries' trade logistics performance will have a significant effect towards increasing bilateral trade flows. This will enhance intra-regional trade of Africa. In conclusion, these findings provide further support for the relevance of the improvement of countries' trade logistics performance to enhance intra-regional trade in Africa.

\section{Practical implication}

There are ongoing efforts to implement the continental free trade agreement of Africa with an aim of boosting intraregional trade. African countries shall grasp the opportunities offered by the region's continental free trade area. This article argues the relevance of trade logistics performance in the process of boosting intra-regional trade of Africa. Generally, African countries had faced with formidable challenges in trade logistics areas such as logistics infrastructure developments, customs and border clearance, and competence and quality of logistics services. These will hinder the effective implementation of the Continental Free Trade Area of Africa. Addressing the continent trade- and transport-related infrastructure development requires coordinated efforts with the purpose of enhancing a linkage between production-distribution-consumption in crossborder transactions. This requires active participation by all stakeholders including government institutions, private firms and investors (Mariam 2018).

As road transportation had used for over $80 \%$ of passenger and freight transportation in Africa (Mariam 2018), it is important to enlarge cross-border logistics infrastructure constructions towards improving African countries' logistics connectivity and service deliveries. There are several cross-border projects undertaken in Africa. For example, in East Africa Burundi-Rwanda-Dar, 1672 km standard gauge railway is under construction. This railway project will link landlocked Burundi and Rwanda to the port of Dar es Salaam (Tanzania). The other large infrastructure project is the Lamu Port-South SudanEthiopia-Transport (LAPSSET) corridor programme that will connect Lamu Port (Kenya) to Juba (South Sudan) to Addis Ababa (Ethiopia). LAPSSET corridor includes several logistics projects such as highways, railways, ports, oil pipeline and airport projects (Deloitte 2017).

Countries with low logistics performance can cut their red tape, non-transparent rules and excessive physical inspection through implementing comprehensive border management reform comprising all relevant sectors and agencies (Arvis et al. 2012). Border management reform has led to initiatives such as a single window system and onestop border post (Barka 2012). WTO Trade Facilitation Agreement article 10.4 requires member states to apply single window for submission of documentation and/or data required for export, import or transit. The information supplied once via the 'single window' will not be asked again by other border agencies. The right implementation of such a system requires a strong commitment by all border agencies (International Trade Centre 2013). In Rwanda, the single window system reduced the time taken to clear goods from $34 \mathrm{~h}$ in 2010 to $23 \mathrm{~h}$ in 2014. Trade Net, Kenya's single window system, has simplified cargo clearance process with an expected saving of \$150-\$250 million during the first 3 years (WTO 2018). African Alliance for Electronic Commerce (AAEC) has taken the initiative for promoting 
single window system in Africa. Beyond the national boundaries, national single window platforms shall be connected by a Regional Single Windows to improve trade flows in Africa and enable African countries to be more competitive on the global markets. West African Economic and Monetary Union single window can be a good example for this (AACE 2017).

Private sectors' active participation at the national level will have a paramount contribution to improve trade logistics competencies. In fact, the public sector plays a critical role in preparing regulation conducive to increase private sector involvement and allocation of investments to enhance competitiveness. Private firm's operations such as freight forwards and logistics service providers would have significant contributions in adding values for countries' quality logistics service deliveries in international trade (Burmaoglu \& Sesen 2011). Thus, besides strengthening public sectors role, African countries shall give emphasis in creating conducive legal environments to attract investment and active participation of private firms in global logistics.

Landlocked African countries depend on their coastal neighbours for extra-African trade. Implementing AfCFTA will benefit more landlocked countries in Africa. This is true because cargoes flow between landlocked countries and their neighbours will be transported by land rather than depending on their transit corridors for access to the sea (African Export-Import Bank 2018). Enhancing trade flows between landlocked countries and their neighbours requires infrastructure developments that will transform landlocked countries into land linked through efficient road and railway transport systems. Regarding infrastructure development cost recovery, Arvis and Dairabayeva (2014) recommended landlocked developing countries to apply the vignette troll system.

Successful improvements in African countries' trade logistics performance such as logistics infrastructures, customs and border clearance and logistics service quality will enhance African countries' supply chain deliveries, that is, on-time delivery of shipments, ease of arranging competitively priced international shipments and high-level of tracking and tracing consignments. This will enhance trade between African countries. Thus, African countries could continue to improve their trade logistics performance to increase intraregional trade flows. This will have a paramount contribution to the successful implementation of the Continental Free Trade Area of Africa.

\section{Acknowledgements Competing interests}

The author declares that he has no financial or personal relationships that may have inappropriately influenced him in writing this article.

\section{References}

African Alliance for E-Commerce (AACE), 2017, Practical implementation guide of single windows for foreign trade, Version 2. Dakar-Sénégal.

African Export-Import Bank, 2018, African trade report 2018. Boosting intra-African trade: Implications of the African continental free trade area agreement, Cairo, Egypt: Afreximbank.

African Tax Administration Forum, 2017, African tax outlook 2017, Pretoria, South Africa: ATAF Secretariat.

African Union (AU), 2018, Agreement establishing the African continental free trade area, SIGNED at Kigali, on March 2018. Kigali, Rwanda: African Union.

Anderson, J.E. \& Van Wincoop, E., 2004, 'Trade costs', Journal of Economic Literature 42(3), 691-751. https://doi.org/10.1257/0022051042177649

Arvis, J.F. \& Dairabayeva, K., 2014, Improving trade and transport for landlocked developing countries: A ten-year review, Washington: World Bank, and UNOHRLLS.

Arvis, J.F., Monica, A.M., John, P., Lauri, O. \& Tapio, N., 2007, Connecting to compete trade logistics in the global economy: The logistics performance index and its indicators, Washington, DC: The World Bank.

Arvis, J.F., Mustra, A.M., Ojala, L., Shepherd, B. \& Saslavsky, D., 2010, Connecting to compete 2010. Trade logistics in the global economy: The logistics performance index and its indicators, Washington, DC: The World Bank.

Arvis, J.F., Mustra, A.M., Ojala, L., Shepherd, B. \& Saslavsky, D., 2012, Trade logistics in the global economy: The logistics performance index and its indicators, Washington, DC: The World Bank.

Arvis, J.F., Saslavsky, D., Ojala, L., Shepherd, B., Busch, C. \& Raj, A., 2014, Connecting to compete 2014. Trade logistics in the global economy: The logistics performance index and its indicators, Washington, DC: The World Bank.

Arvis, J.F., Saslavsky, D., Ojala, L., Shepherd, B., Busch, C., Raj, A.T. et al., 2016, Connecting to compete 2016: Trade logistics in the global economy - The logistics performance index and its indicators, World Bank, DC: The World Bank.

Bacchetta, M., Beverelli, C., Cadot, O., Fugazza, M., Grether, J.M., Helble, M. et al., 2015, A practical guide to trade policy analysis, Switzerland: World Trade Organization.

Balassa, B., 1961, The theory of economic integration, Richard D. Irwin, Homewood, IL.

Barka, H.B., 2012, 'Border posts, checkpoints, and intra-African trade: Challenges and solutions', OPEV Newsletter, pp. 1-18.

Barnekow, S.E. \& Kulkarni, K.G., 2017, 'Why regionalism? A look at the costs and benefits of regional trade agreements in Africa', Global Business Review 18(1), 99-117. https://doi.org/10.1177/0972150916666881

Bolaños, A.B., 2016, A step further in the theory of regional integration: A look at the Unasur's integration strategy. France: HAL.

Burmaoglu, S. \& Sesen, H., 2011, 'Analyzing the dependency between national logistics performance and competitiveness: Which logistics competence is core for national strategy?', Journal of Competitiveness 3, 4-22.

Busch, C., 2015, The logistics performance index (LPI), UN ESCAP/ADB/OECD Trade Facilitation Implementation and Performance Monitoring Workshop, Wuhan.

Centre d'Études Prospectives et d'Informations Internationales (CEPII), viewed 18 August 2018, from http://www.cepii.fr/cepii/en/bdd_modele/bdd.asp.

Chowdhury, A.K. \& Erdenebileg, S., 2006, Geography against development: A case for landlocked developing countries, United Nations.

Dabrowski, M. \& Myachenkova, Y., 2018, 'Free trade in Africa: An important goal but not easy to achieve', Bruegel, 13 April, viewed n.d., from http://bruegel. org/2018/04/free-trade-in-africa-an-important-goal-but-not-easy-to-achieve/.

Deloitte, 2017, A shift to more but less Africa Construction Trends Report 2017. United Kingdom; Deloitte Touche Tohmatsu Limited.

Donaldson, D., Jinhage, A. \& Verhoogen, E., 2017, Beyond borders: Making transport work for African trade, IGC Growth Brief Series, 9. London: International Growth Centre.

Economic Commission for Africa, 2017, Economic report on Africa 2017: Urbanization and industrialization for Africa's transformation, United Nations, Addis Ababa, Ethiopia.

Farrell, M., Hettne, B. \& Van Langenhove, L., 2005, Global politics of regionalism: Theory and practice, London: Pluto Press.

Foster, V. \& Briceño-Garmendia, C.M. (eds.), 2009, Africa's infrastructure: A time for transformation, Washington: The World Bank.

Geda, A. \& Seid, E.H., 2015, 'The potential for internal trade and regional integration in Africa', Journal of African Trade 2(1-2), 19-50. https://doi.org/10.1016/j. joat.2015.04.001

Hausman, W.H., Lee, H.L. \& Subramanian, U., 2005, Global logistics indicators, supply chain metrics, and bilateral trade patterns, The World Bank. Viewed from https:// www.nber.org/papers/w0172.

Havenga, J.H., Simpson, Z.P., King, D., De Bod, A. \& Braun, M., 2016, Logistics Barometer South Africa 2016, Stellenbosch University, Stellenbosch, South Africa.

Heckman, J.J., 1977, 'Sample selection bias as a specification error (with an application to the estimation of labor supply functions), NBER working paper no. $17247(1)$ 153-162. https://doi.org/10.3386/w0172

Hoekman, B. \& Nicita, A., 2011, 'Trade policy, trade costs, and developing country trade', World Development 39(12), 2069-2079. https://doi.org/10.1016/j. worlddev.2011.05.013 
International Trade Centre, 2013, WTO trade facilitation agreement a business guide for developing countries. Geneva, Switzerland: International Trade Centre.

Korinek, J. \& Sourdin, P., 2011, To what extent are high-quality logistics services trade facilitating?, OECD Trade Policy Papers, No. 108, OECD Publishing, Paris.

Mariam, A.L., 2018, Boosting Intra-African trade hindrances, opportunities and the continental free trade area, Bertelsmann Stiftung Focus Paper, Gütersloh: Bertelsmann Stiftung.

Martí, L., Puertas, R. \& García, L., 2014, 'The importance of the logistics performance index in international trade', Applied Economics 46(24), 2982-2992. https://doi.o $\mathrm{g} / 10.1080 / 00036846.2014 .916394$

McLinden, G., Fanta, E., Widdowson, D. \& Doyle, T., 2011, Border management modernization, World Bank, Washington, DC.

Morrow, J.D., 1999, 'How could trade affect conflict?', Journal of Peace Research 36(4) 487. https://doi.org/10.1177/0022343399036004006

Mwaba, G., 2017, African Export-Import Bank 'Afreximbank', Geneva: African ExportImport Bank.

New Partnership for Africa's Development (NEPAD), 2016. Concept Note - Launch of the MoveAfrica Intiative, 11 May 2016, Kigali, Rwanda. https://www.nepad.org/ publication/concept-note-launch-moveafrica-initiative.

Ngepah, N. \& Udeagha, M.C., 2018, 'African regional trade agreements and intraAfrican trade', Journal of Economic Integration 33(1), 1176-1199. https://doi. org/10.11130/jei.2018.33.1.1176

Nordås, H.K., Pinali, E. \& Grosso, M.G., 2006, Logistics and time as a trade barrier OECD Trade Policy Working Papers, No. 35, OECD Publishing

Ogunyemi, O.I., 2017, 'African continental free trade area: Challenges and opportunities for small and medium scale enterprises in Nigeria', American Journal of Business, Economics and Management 5(4), 30.

Portugal-Perez, A. \& Wilson, J.S., 2009, 'Why trade facilitation matters to Africa', World Trade Review 8(3), 379-416. https://doi.org/10.1017/S147474560900439X

Portugal-Perez, A. \& Wilson, J.S., 2012, 'Export performance and trade facilitation reform: Hard and soft infrastructure', World Development 40(7), 1295-1307. https://doi.org/10.1016/j.worlddev.2011.12.002

Puertas, R., Martí, L. \& García, L., 2013, Logistics performance and expor competitiveness: European experience, Springer Science+Business Media, New York.

Puertas, R., Martí, L. \& García, L., 2014, 'Logistics performance and export competitiveness: European experience', Empirica 41(3), 467-480. https://doi. org/10.1007/s10663-013-9241-z

Rippel, B., 2011, Why trade facilitation is important for Africa, Africa Trade Policy Notes, 27. The World Bank.

Rocha, N. \& Freund, C.L., 2010, What constrains Africa's exports, Staff Working Pape ERSD-2010-07. The World Bank.

Russett, B., 1967, International regions and international systems, Rand-McNally, Chicago, IL.

Saslavsky, D. \& Shepherd, B., 2014, Facilitating international production networks: The role of trade logistics, World Bank Policy Research Working Paper 6224 23(7), 979-999. https://doi.org/10.1080/09638199.2013.811534
Saygili, M., Peters, R. \& Knebel, C., 2017, African continental free trade Area: Challenges and opportunities of tariff reductions, Policy Issues in International Trade and Commodities, Study Series, United Nations, New York.

Saygili, M., Peters, R. \& Knebel, C., 2018, African continental free trade area: Challenges and opportunities of tariff reductions, Geneva: UNCTAD.

Seid, E.H., 2013, Regional integration and trade in Africa: Augmented gravity mode approach. Johannesburg, South Africa: African Economic Conference.

Shepherd, B., 2013, The gravity model of international trade: A user guide, United Nations Publication, Thailand.

Soja, E.W., 2009, Regional planning and development theories. International Encyclopedia of Human Geography, Elsevier.

The Economist, 2014, Risk and reward: The Gulf's push into African infrastructure, London: The Economist Intelligence Unit Limited.

United Nations Conference on Trade and Development (UNCTAD), 2015, The continental free trade area: Making it work for Africa, No. 44. New York and Geneva: United Nations Publication.

United Nations Conference on Trade and Development (UNCTAD), 2016, African continental free trade Area: Policy and negotiation options for trade in goods, United Nations, New York.

United Nations Conference on Trade and Development (UNCTAD), 2018, From regional economic communities to a continental free trade area: Strategic tools to assist negotiators and agricultural policy design in Africa, Geneva: UNCTAD. UNCTAD/WEB/ DITC/2017/1. https://unctad.org/en/PublicationsLibrary/webditc2017d1_en.pdf.

UN Office of the Special Adviser on Africa (OSAA), 2015, Financing Africa's Infrastructure Development, Policy Brief, 2015. New York: OSAA.

UN-OHRLLS, 2014, Vienna programme of action for landlocked developing countries for the decade 2014-2024, Vienna: UN-OHRLLS.

World Bank, 2016a, Doing business 2016: Measuring regulatory quality and efficiency, Washington: World Bank Group.

World Bank, 2016b, Time to export, border compliance (hours), viewed 15 August 2018, from https://data.worldbank.org/indicator/IC.EXP.TMBC.

World Bank, 2016c, Logistics performance index: Overall (1=low to 5=high), viewed 12 September 2018, from https://lpi.worldbank.org/.

World Bank Group, 2014, 'Improving trade and transport for landlocked developing countries', in 2nd United Nations Conference on Landlocked Developing Countries (LLDCS). Washington: UN-OHRLLS.

World Bank Open Data, viewed 18 August 2018, from https://data.worldbank.org/.

World Economic Forum, 2013, The Africa Competitiveness Report 201. Geneva: World Economic Forum.

World Trade Organization (WTO), 2013, World trade report 2013: Factors shaping the future of world trade.

World Trade Organization (WTO), 2017, World Trade Statistical Review 2017. World Trade Organization Geneva, Switzerland.

World Trade Organization (WTO), 2018, Trade facilitation agreement facility, Geneva, Switzerland.

UN Comtrade Database, viewed 18 August 2018, from https://comtrade.un.org/data/. 